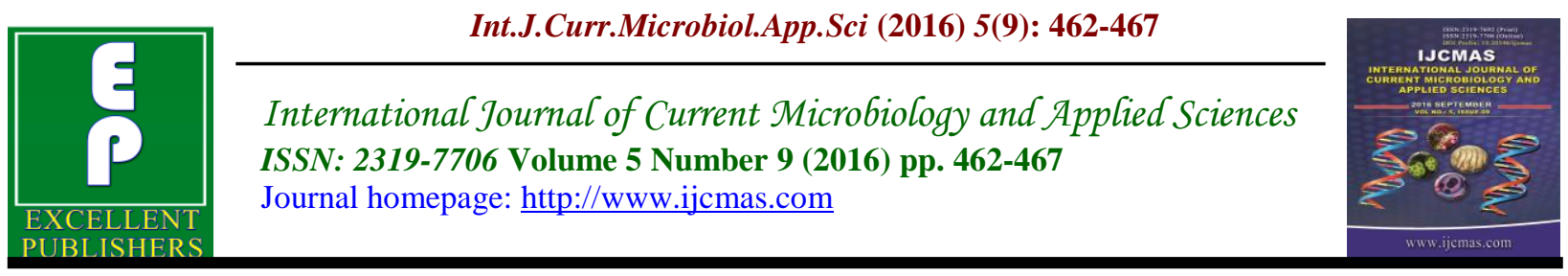

Original Research Article

http://dx.doi.org/10.20546/ijcmas.2016.509.050

\title{
Bioprospecting of Endophytic Bacteria from Zingiber officinale with Antibacterial Activities
}

\author{
Rohini Sabu and E.K. Radhakrishnan* \\ School of Biosciences, Mahatma Gandhi University, Kottayam, Kerala, India \\ *Corresponding author
}

\section{A B S T R A C T}

\begin{tabular}{l} 
Ke y w or d s \\
Endophytic \\
bacteria, \\
Zingiber officinale, \\
16S rDNA, \\
antibacterial \\
activity. \\
\hline Article Info \\
\hline Accepted: \\
18 August 2016 \\
Available Online: \\
10 September 2016
\end{tabular}

Endophytes contribute a major role in biodiversity. They are well known for its uniqueness and antimicrobial properties. In our study endophytic bacteria were isolated from surface sterilized rhizome of Zingiber officinale. Sodium hypochlorite and ethanol were used for surface sterilization. Endophytic bacteria were isolated and purified. DNA of the isolates was amplified by $16 \mathrm{~S}$ rDNA and was identified. All the five of them belonged to Bacillus. These isolates were screened for antibacterial activity against a panel of five human pathogens namely Bacillus subtilis, Klebsiella pneumoniae, Escherichia coli, Staphylococcus aureus and Salmonella typhi by perpendicular streaking. All of the endophytic bacteria except one showed prominent antibacterial activity. Methanolic extracts of these isolates also confirmed potential antibacterial activity.

\section{Introduction}

New types of pathogens are evolving with an alarming rate, complicating the treatment of such infectious diseases; demanding the need of novel and potential antibiotics. The rising antibiotic resistance is globally tackled by natural products derived from plants and micro organisms. The latter is currently believed to be more reliable and faster available source of antibiotics for therapeutic options for innumerable diseases. Since the discovery of taxol (Stierle et al., 1993), researchers now pay attention to microorganisms that live inside the plant tissue, known as endophytes. They spend most of their lifetime inside the plant without causing any disease symptom. They inhabit in different parts of the plant including roots, stems, leaves, flowers, fruits and seeds occupying in inter or intracellular spaces of the host plant. It is remarkable that, approximately 3,00,000 of plant species in earth probably harbors different types of endophytes which contributes enormous biodiversity (Bérdy, 2005). Isolation of novel endophytes with novel and potent bioactive compound can be done by selecting plants from unusual niches as well as from plants with ethanobotanical history. Ginger is such a plant with ethanobotanical history which has been used for digestive ailments from time immemorial (Petrovska, 2012). 
There are many reports on endophytes producing secondary metabolites in their stationary phase with immense applications such as antibacterial, antifungal, anticancer, antiviral, antioxidant, insecticide, anti diabetic and immunosuppressive activities (Strobel, 2003; Wiyakrutta et al., 2004; Zhang et al., 2006; Xu et al., 2007; Shweta et al., 2013). In the current study we have isolated endophytic bacteria from Zingiber officinale with antibacterial activity.

\section{Materials and Methods}

\section{Isolation of endophytic bacteria}

The endophytic bacteria were isolated from rhizomes of ginger (Zingiber officinale). They were collected from the Kerala Agricultural College, Mannuthy, Thrissur. The rhizomes were cleaned and washed under running tap water for several minutes. The scales were then removed and the rhizome was treated with teepol by vigorous shaking for 10 minutes followed by washing with distilled water.

This was then dipped in $70 \%$ alcohol for 1 minute and washed with distilled water. Further, the rhizomes were treated with $2 \%$ sodium hypochlorite for 10 minutes. Then it was washed with sterilized distilled water several times and the final wash was kept for sterility check. After surface sterilization, the outer portions of the rhizome were removed and were cut it into small pieces under sterile conditions. Carefully the pieces were placed into Tryptic soya agar and King's B agar supplemented with $50 \mu \mathrm{g} / \mathrm{ml}$ of nalidixic acid and $50 \mu \mathrm{g} / \mathrm{ml}$ of nystatin and was kept for incubation at $28^{\circ} \mathrm{C} \pm 2{ }^{\circ} \mathrm{C}$ for 2-5 days. The final wash was also spread plated on the same media to check the sterility.

\section{Identification of the isolated bacteria}

The molecular identification of bacteria was carried out by $16 \mathrm{~S}$ r DNA sequence based method. Here, genomic DNA from purified bacteria was isolated using commercially available bacterial genomic DNA isolation kit (Chromous Biotech). The selected isolates were inoculated into $30 \mathrm{ml}$ of Luria Bertani's broth in a 100- mL conical flask and incubated at $28^{\circ} \mathrm{C}$ for 5 days at $100 \mathrm{rpm}$. Then the cells were collected by centrifugation and the pellet (approximately $500 \mathrm{mg}$ ) was used for DNA isolation as per manufacturer's protocol. The isolated DNA was further analyzed by electrophoresis using $0.8 \%$ agarose gel.

\section{Polymerase Chain Reaction}

Isolated DNA was used as template for PCR using $16 \mathrm{~S}$ rDNA specific primers 16SF (5'AgA gTTTgA TCM Tgg CTC Ag -3') and 16SR (5'-TAC ggY TAC CTT gTTACg ACT T-3'). The sequence of the primers was selected based on the previous reports (Chun and Goodfellow 1995). PCR was carried out in a final volume of $50 \mathrm{ul}$ with $50 \mathrm{ng}$ of genomic DNA, 20 pmol of each primer, 200 $\mu \mathrm{M}$ of each dNTPs, $5 \mu \mathrm{l}$ of 10X PCR buffer and $1.25 \mathrm{U}$ of TaqDNA polymerase in a Mycycler $^{\mathrm{TM}}$ (Bio-Rad, USA). The PCR conditions used were; 5 minutes denaturation at $94^{\circ} \mathrm{C}$, followed by 35 cycles of 60 seconds denaturation at $94^{\circ} \mathrm{C}, 60$ seconds annealing at $45^{\circ} \mathrm{C}, 2$ minutes extension at $72^{\circ} \mathrm{C}$, and a final extension for 7 minutes at $72^{\circ} \mathrm{C}$. PCR products were visualized by $1.2 \%(\mathrm{w} / \mathrm{v})$ agarose gel. The products were then gel purified and was used for sequencing. The sequence data thus obtained was subjected to similarity search using BLAST analysis.

\section{Screening of antimicrobial activity of endophytic bacteria}

Preliminary antibacterial activity of endophytic bacteria were tested against Salmonella typhi, Staphylococcus aureus, 
Bacillus subtilis, Escherichia coli and Klebsiella pneumoniae by perpendicular streaking on Nutrient agar (NA) plates. Endophytic bacteria were streaked as a line on the center and the pathogens perpendicular to the endophyte. The plates were incubated at room temperature for 24 hours and observed.

\section{Fermentation and extraction procedures}

The endophytic bacteria were inoculated into $100 \mathrm{ml}$ nutrient broth for 10 days at $28^{\circ} \mathrm{C}, 120 \mathrm{rpm}$ in a rotary shaker. After the fermentation processes, culture broth was centrifuged at $10,000 \mathrm{~g}$ for $10 \mathrm{mins}$ and the supernatants were taken. The culture supernatants obtained were extracted twice with ethyl acetate and concentrated to dryness under reduced pressure in a rotary vacuum evaporator at $40^{\circ} \mathrm{C}$ and was redissolved in $2 \mathrm{ml}$ of methanol. Then the methanolic extracts were used for antibacterial screening.

\section{Screening of antimicrobial activity of endophytic bacteria}

Antibacterial activity of endophytic bacteria were tested against Salmonella typhi, Staphylococcus aureus, Bacillus subtilis Escherichia coli and Klebsiella pneumoniae by well diffusion method on Muller Hinton agar (MHA) plates.

Wells were made on the Muller- Hinton agar plates using a gel puncture and plates were inoculated by swabbing the bacterial pathogens (0.5 McFarland turbidity standards) to create a confluent lawn of bacterial growth. Then $40 \mu \mathrm{L}$ of the methanolic extracts from each bacterium were added into each well. For all the activity analysis, crude methanolic extracts prepared from all the purified bacteria were used.

\section{Results and Discussion}

\section{Isolation and Identification of Endophytic Bacteria from $Z$. officinale}

The asymptomatic rhizomes of Zingiber officinale served as sources of endophytic bacteria. They were surface sterilized and rhizome pieces were kept on TSA and King's B medium. The effectiveness of the surface sterilization protocol was checked by pouring $1 \mathrm{ml}$ from the last wash. Rinsed water of each sample showed no microbial growth on both the media after incubation at $28^{\circ} \mathrm{C}$ for 2 weeks, indicating that the epiphytic microbes were completely removed by this surface sterilization procedures. Indeed, the major key to succeed in isolating and studying endophytes is to ensure the sterility of the plant surface (Hallmann et al., 1997).

The isolation of endophytic bacteria from rhizome of $Z$. officinale resulted in the identification of 5 morphologically distinct isolates named as ZB1, ZB2, ZB3, ZB4, and ZB5. The result of BLAST analysis along with accession number of submitted $16 \mathrm{~S}$ rDNA sequence of purified bacteria is summarized as Table 1.

The isolates ZB1 to ZB5 showed maximum identity to Bacillus sp. El-Deeb et al., (2013) reported the isolation of 28 endophytic bacterial isolates from different organs of $P$. tenuiflorus plant, which belonged to Bacillus sp., Bacillus megaterium, Bacillus pumilus, Bacillus licheniformis, Micrococcus luteus, Paenibacillus sp., Pseudomonas sp., and Acinetobacter calcoaceticus. De Oliveira Costa et al reported that (de Oliveira Costa et al., 2012) 23 different genera were isolated from common bean (Phaseolus vulgaris). 
Preliminary screening of antimicrobial activity of endophytic bacteria

Perpendicular streaking showed that all the five shows antibacterial activity against the selected panel of pathogens. Highest activity was shown by ZB 5 against Staphylococcus aureus and Salmonella typhi. (Fig. 1). All the five isolates were subjected for small scale fermentation and extraction.

Table.1 Summarized result of BLAST of endophytic bacteria from Z. officinale with result of its identical

\begin{tabular}{|c|c|l|l|l|}
\hline Sl.No. & $\begin{array}{l}\text { Name of the isolates } \\
\text { with accession } \\
\text { number }\end{array}$ & $\begin{array}{l}\text { Closest NCBI } \\
\text { match with } \\
\text { accession number }\end{array}$ & $\begin{array}{l}\text { Percentage of } \\
\text { Identity }\end{array}$ & $\begin{array}{c}\text { The isolate is } \\
\text { identified as }\end{array}$ \\
\hline 1 & ZB 1 & $\begin{array}{l}\text { Bacillus sp TKB } \\
\text { beta 1., KT719720 }\end{array}$ & $100 \%$ & Bacillus sp. \\
\hline 2 & ZB 2 & $\begin{array}{l}\text { Bacillus sp. strain } \\
\text { ISE_26;KX035060 }\end{array}$ & $99 \%$ & Bacillus sp \\
\hline 3 & ZB 3 & $\begin{array}{l}\text { Bacillus cereus } \\
\text { strain SIIA_Pb_E3; } \\
\text { KX036611 }\end{array}$ & Bacillus cereus \\
\hline 4 & ZB 4 & $\begin{array}{l}\text { Bacillus cereus } \\
\text { strain HG10; } \\
\text { KX430857 }\end{array}$ & $\begin{array}{l}\text { Bacillus sp. GG3; } \\
\text { LC055679 }\end{array}$ & Bacillus cereus \\
\hline 5 & ZB 5 & Bacillus sp. \\
\hline
\end{tabular}

Table.2 Summary of antimicrobial activity analysis of the endophytic bacteria from

\begin{tabular}{|l|c|c|c|c|c|}
\hline \multirow{2}{*}{ Isolates } & \multicolumn{5}{|c|}{ Pathogens } \\
\cline { 2 - 6 } & S. aureus & K. pneumoniae & E. coli & B.subtilis & S.typhi \\
\hline ZB1 & ++ & - & + & + & ++ \\
\hline ZB2 & + & - & + & + & ++ \\
\hline ZB3 & - & - & - & - & - \\
\hline ZB4 & + & + & ++ & - & ++ \\
\hline ZB5 & +++ & - & ++ & + & +++ \\
\hline
\end{tabular}


Fig.1 Antibacterial activity of endophytic bacteria by perpendicular streaking method
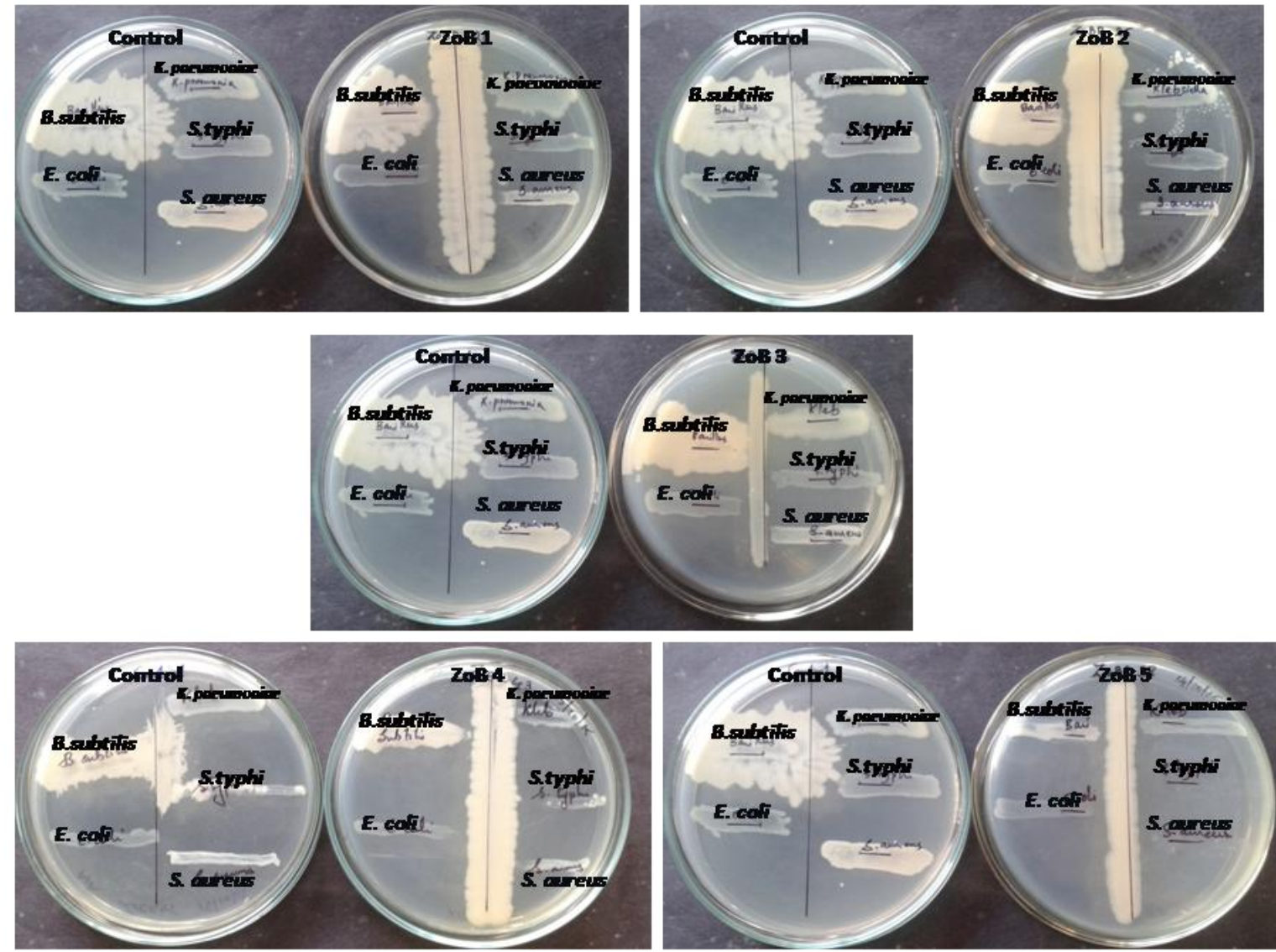

Methanolic extracts of all the isolates were used to test antagonistic activity against pathogenic bacteria. Except ZB 3 all the other isolates exhibited antagonistic activity against at least one of the test bacterial strains. Isolate $\mathrm{ZB} 5$ showed excellent antibacterial activity against Salmonella typhi and Staphylococcus aureus as revealed by the size of the zone of inhibition (Table 2). (El-Deeb et al., 2013) reported that endophytic bacteria isolated from Plectranthus tenuiflorus showed considerable antimicrobial activities against a panel of human pathogenic microorganisms (Staphylococcus aureus, Escherichia coli, Klebsiella pneumoniae, Streptococcus agalactiae, Proteus mirabilis, and Candida albicans). The bioactivity of endophytic bacteria and human pathogens are highly promising. These reports give clues about the presence of promising bioactive compounds in the isolated strains as indicated by their antimicrobial effects.

In conclusion, this study evidenced that Zingiber officinale is a potential resource for bioactive endophytic bacteria with its antibacterial activities. Further investigations on plant endophytic bacteria are needed for the discovery of bioactive compounds. This aspect of antimicrobial activity will be further investigated to enhance production of secondary metabolites of interest.

\section{Acknowledgment}

The authors express gratitude towards The Kerala State Council for Science, Technology and Environment for the 
KSCSTE - Fellowship (Council Order No.010 - 40/FSHP/2010CSTE).

\section{References}

Bérdy, J. 2005. Bioactive Microbial Metabolites. J. Antibiotics, 58(1): 126.

Chun, J., M. Goodfellow. 1995. A Phylogenetic Analysis of the Genus Nocardia with 16S rRNA Gene Sequences. Int. J. Systematic Bacteriol., 45(2): 240-245.

de Oliveira Costa, L.E., M.V. de Queiroz, A.C. Borges, C.A. de Moraes, E.F. de Araujo. 2012. Isolation and characterization of endophytic bacteria isolated from the leaves of the common bean (Phaseolus vulgaris). Braz. J. Microbiol., 43(4): 1562-1575.

El-Deeb, B., K. Fayez.,Y. Gherbawy. 2013. Isolation and characterization of endophytic bacteria fromPlectranthus tenuiflorusmedicinal plant in Saudi Arabia desert and their antimicrobial activities. J. Plant Interactions, 8(1): 56-64.

Hallmann, J., A. Quadt-Hallmann, W.F. Mahaffee., J.W. Kloepper. 1997. Bacterial endophytes in agricultural crops. Canadian J. Microbiol., 43(10): 895-914.

Petrovska, B.B. 2012. Historical review of medicinal plants' usage. Pharmacognosy Reviews. 6(11): 1-5.

Shweta, S., J.H. Bindu, J. Raghu, H.K. Suma, B.L. Manjunatha, P.M.
Kumara, G. Ravikanth, K.N. Nataraja, K.N. Ganeshaiah, R. Uma Shaanker. 2013. Isolation of endophytic bacteria producing the anti-cancer alkaloid camptothecine from Miquelia dentata Bedd. (Icacinaceae). Phytomed., 20(10): 913-917.

Stierle, A., G. Strobel, D. Stierle. 1993. Taxol and taxane production by Taxomyces andreanae, an endophytic fungus of Pacific yew. Sci., 260(5105): 214-216.

Strobel, G.A. 2003. Endophytes as sources of bioactive products. Microbes and Infect., 5(6): 535-544.

Wiyakrutta, S., N. Sriubolmas, W. Panphut, N. Thongon, K. Danwisetkanjana, N. Ruangrungsi, V. Meevootisom. 2004. Endophytic fungi with anti-microbial, anti-cancer and anti-malarial activities isolated from Thai medicinal plants. World J. Microbiol. Biotechnol., 20(3): 265-272.

Xu, D., X. Xia, N. Xu, L. An. 2007. Isolation and identification of a novel endophytic bacterial strain with antifungal activity from wild blueberryVaccinium uliginosum. Annals of Microbiol., 57(4): 673-676.

Zhang, Q., X. Kang, W. Zhao. 2006. Antiangiogenic effect of low-dose cyclophosphamide combined with ginsenoside $\operatorname{Rg} 3$ on Lewis lung carcinoma. Biochem. Biophysical Res. Сотти., 342(3): 824-828.

\section{How to cite this article:}

Rohini Sabu and E.K. Radhakrishnan. 2016. Bioprospecting of Endophytic Bacteria from Zingiber officinale with Antibacterial Activities. Int.J.Curr.Microbiol.App.Sci. 5(9): $462-467$. doi: http://dx.doi.org/10.20546/ijcmas.2016.509.050 